\title{
Immunomodulatory potential of marine secondary metabolites against bacterial diseases of shrimp
}

\author{
Joseph Selvin $^{\text {a,* }}$, A.J. Huxley ${ }^{\mathrm{a}}$, A.P. Lipton ${ }^{\mathrm{b}}$ \\ ${ }^{a}$ Department of Biotechnology, Malankara Catholic College, Mariagiri, Kaliakavilai-629 153, \\ Kanyakumari District, India \\ ${ }^{\mathrm{b}}$ Marine Biotechnology Laboratory, Central Marine Fisheries Research Institute, Vizhinjam-695 521, \\ Thiruvananthapuram, India
}

Received 14 March 2003; received in revised form 20 May 2003; accepted 23 May 2003

\begin{abstract}
Shrimp disease management using bioactive marine secondary metabolites (MSMs) was developed as a package of practice for the sustainable shrimp farming. Therefore, the effect of MSMs on the host defense factors of shrimp was evaluated in the present study. Findings indicated that Ulva diet significantly increase the defense factors such as haemogram, agglutination index, phagocytic rate, bacterial clearance and serum bactericidal activity of treated shrimps over the control group. Based on the gut bacterial load, Ulva diet was considered as proactive drug whereas Dendrilla diet was determined as a curative agent.
\end{abstract}

(C) 2004 Elsevier B.V. All rights reserved.

Keywords: Disease-management; Immunostimulant; Shrimp disease; Penaeus monodon; Ulva fasciata; Dendrilla nigra; Marine secondary metabolites

\section{Introduction}

In shrimp, the first lines of defense are elicited by haemocytes through phagocytosis, encapsulation and nodule formation. The phagocytic activity is enhanced considerably by the activation of prophenoloxidase (Pro-PO) system localized in the semigranular and granular haemocytes (Hose et al., 1990). Among the factors concerning the humoral defense system, the phenoloxidase (PO), bactericidin and lectins are considered as

* Corresponding author.

E-mail address: selvinj@rediffmail.com (J. Selvin). 
important (Azad et al., 1995). These defense factors in the cellular systems cooperatively provide a defense barrier against invading pathogenic organisms found in the environment. These systems have a mutual interaction and construct an elaborate network of host immunodefense. Reports on the microbicidal activity of crustacean haemolymph clearly indicated that about $75 \%$ of the encountered bacteria are eliminated within $10 \mathrm{~min}$ of exposure (Sung et al., 1996). The effect of agglutinins, which cause agglutination of foreign particles, is less, short-lived and non-specific (Adams, 1991). Therefore, elicitation of non-specific defense factors against bacterial infection is emerging as an effective proactive management strategy. Albeit MSMs have been found to be effective for controlling bacterial diseases of shrimp (Selvin, 2002; Selvin and Lipton, 2003a,b), the mechanism of action has not been established. The present paper addresses the findings of preliminary experiments carried out to evaluate the influence of MSMs on the host defense system of shrimp.

\section{Materials and methods}

\subsection{Preparation of medicated feed}

MSMs, which showed maximum activity in an in vitro antibacterial study (Selvin, 2002), were used in the present study. The commercial pelleted shrimp grower feed No. 1 (C.P. feeds, Cochin) was used for the preparation of sprayed medicated feed. Based on earlier findings (Selvin and Lipton, 2003a,b), the effective doses of marine alga Ulva fasciata and sponge Dendrilla nigra were 1000 and $500 \mathrm{mg} / \mathrm{kg}$, respectively, and were used for the preparation of medicated feed. The doses were incorporated in the feed by spraying appropriate secondary metabolites on the surface of the feed at a rate of $3.2 \%$ of the shrimp body weight daily (Selvin and Lipton, 2003a).

\subsection{Treatment schedule}

Shrimps with an average body length of 5-6.5 $\mathrm{cm}$ range were reared in the circular high Density Polymer (HDP) tanks at a stocking density of 20 individuals per 2001 of seawater. The tanks were aerated and maintained at $30^{\circ} \pm 2{ }^{\circ} \mathrm{C}$ and $35 \%$ o salinity. The animals were fed with appropriate medicated feed in three equal installments at a rate of $3.2 \%$ of their body weight for a period of 15 days. On the 16 th day of post-treatment, the shrimps were sampled randomly for analysis of defense factors. All analyses were carried out using pooled haemolymph of 20 shrimps and results were expressed as average of triplicate experiments.

\subsection{Determination of host defense factors}

Haemolymph was obtained from the ventral part of the haemocoel of the second abdominal segment using a 25 -gauge needle and a 1-ml syringe filled with $0.2 \mathrm{ml}$ cold modified Alsever's Solution (19.3 mM sodium citrate, $239.8 \mathrm{mM} \mathrm{NaCl}, 182.5 \mathrm{mM}$ glucose, $6.2 \mathrm{mM}$ EDTA in $\mathrm{pH}$ 7.3) as an anticoagulant (Braak et al., 1996). 
Total haemocyte count (THC) and differential haemocyte counts (DHC) were determined after Jones (1962). The phagocytic assay was carried out using formalin-killed bacterial cells of Vibrio fischeri, Escherichia coli, Pseudomonas aeruginosa, Aeromonas hydrophila and Micrococcus luteus. The assay mixture containing $100 \mu \mathrm{l}$ freshly collected haemolymph and $10 \mu$ l formalin-killed bacterial strains $\left(1 \times 10^{7}\right.$ cells $\left./ \mathrm{ml}\right)$ in PBS $(\mathrm{pH} 7.2)$ were mixed on a glass coverslip and incubated in a humidified chamber at $20{ }^{\circ} \mathrm{C}$ for 30 min. The cells were fixed in methanol and stained with May Grunwald-Giemsa for 15 min. The coverslip was turned upside down on a glass microscope slide, and the results were observed under $1000 \times$ magnification. Phagocytic cells (engulfing more than three bacterial cells) were counted over the whole slide and the results were expressed as relative percent of phagocytosis over the control group of shrimps. Agglutination index was evaluated using plasma of haemolymph collected directly in clean dry Eppendorf cups by cutting the telson. The Eppendorf cup was incubated in a sliding position at $20{ }^{\circ} \mathrm{C}$ for 1 h. After incubation, the plasma layer was separated by centrifugation at $5000 \mathrm{rpm}$ for 10 min. The resultant plasma was diluted with phosphate buffered saline (PBS) in a 74-well plate and subsequently, the dilutions was mixed with $10 \mu \mathrm{l}$ of heat or formalin-killed bacterial suspension and the agglutination was observed under $100 \times$ magnification. The index was estimated by the dilution factor.

Antibacterial activity of bactericidins in the plasma was determined by viable plate count method (Sung et al., 1996) and as expressed as the ratio of survival index (RSI) for the treated shrimps to that of the control group. The results were considered positive if the ratio was less than 1 . To determine the rate of bacterial clearance from the haemolymph, shrimp were injected with $0.1 \mathrm{ml} V$. fischeri suspension (containing $10^{6}$ cells $/ \mathrm{ml}$ ) and haemolymph were sampled after 5, 10, 30 and $60 \mathrm{~min}$. The samples were immediately mixed with $7 \mathrm{ml}$ of melted TCBS agar, poured into petri dishes and incubated at room temperature for $18 \mathrm{~h}$. Number of bacterial colonies per plate was counted and divided by the volume of haemolymph collected to determine the number of colony forming units (cfu) per milliliter of haemolymph.

The effect of antibiosis on the normal gut microflora was studied by Total Viable Count (TVC) method. On the 7th day of oral dosing of appropriate MSMs and OTC, the shrimps were randomly sampled for bacterial count analyses. Shrimps were surface sterilized with $70 \%$ ethanol and cut through the mid-ventral line using a pair of sterile scissors. The entire gut was carefully removed and ground in a mortar and pestle (surface sterilized) with $1 \mathrm{ml}$ of sterile PBS. The resultant aliquot was serially diluted with sterile PBS and plated in triplicate in nutrient agar plates. After incubation at $32{ }^{\circ} \mathrm{C}$, the TVC was determined.

\section{Results and discussion}

The haemogram profile of different experimental groups of shrimps varied considerably (Table 1). In the Ulva and Dendrilla treated group, the THC enhanced to 6725 and 6200 cells $/ \mathrm{ml}$, respectively, when compared to that of control group (5437 cells $/ \mathrm{ml}$ ). The DHC also fluctuated widely among the treated and control groups. From Table 1, it could be noted that the infected shrimps had higher percent of eosinophilic granulocytes (EG) $(41.84 \%)$ with a parallel decrease in the percent of prohaemocytes $(\mathrm{PH})(6.21 \%)$. In the 
Table 1

Haemogram profile of control and treated shrimps

\begin{tabular}{lcccc}
\hline Haemolymph count & \multicolumn{2}{l}{ Experimental groups } & & \\
\cline { 2 - 4 } & Control $n=20$ & Infected $n=5$ & Treated $n=20$ & Dendrilla \\
\cline { 3 - 4 } & & & Ulva & 6200.63 \\
\hline THC (cells/ml) & 5437.50 & 9185.71 & 6725.00 & 15.68 \\
DHC (\%) & & 6.21 & 12.38 & 25.58 \\
(i) PH & 15.57 & 17.35 & 24.76 & 35.51 \\
(ii) HH & 20.49 & 34.69 & 33.33 & 23.25 \\
(iii) IG & 39.34 & 41.84 & 29.52 & \\
(iv) EG & 24.59 & & & \\
\hline
\end{tabular}

$n=$ No. of shrimp sampled for haemolymph collection.

apparently normal shrimp, the EG and $\mathrm{PH}$ were $24.59 \%$ and $15.57 \%$, respectively. The group of shrimps treated with Dendrilla extract did not show variations (which is comparable to the control group) while the Ulva-treated group had EG and $\mathrm{PH}$ of $29.52 \%$ and $12.38 \%$, respectively. The percent of hyaline haemocytes $(\mathrm{HH})$ enhanced in the Ulva- and Dendrilla medicated shrimps to $24.76 \%$ and $25.58 \%$, respectively. The $\mathrm{HH}$ value of control group was accounted for $20.49 \%$. In the case of intermediate granulocytes (IG), the treated shrimps showed declined values $333.33 \%$ for Ulva and $35.51 \%$ for Dendrilla) over the control group (39.34\%).

Crustacean haemocytes play important roles in the host immune response including recognition, phagocytosis, melanization, cytotoxicity and cell to cell communication (Johansson et al., 2000). The semigranular haemocytes were reported to be the primary cells involved in the phagocytosis of foreign particles in shrimp (Bachere et al., 1995; Soderhall and Cerenius, 1992). Granular haemocytes were also reported to be capable of phagocytosing foreign material but with less frequency than the smaller ones (Hose and Martin, 1989). However, granular cells have been proven to play a significant role in the shrimp defense system due to their antibacterial activity (Chisholm and Smith, 1995). The smallest and least numerous hyaline cells were also considered as phagocytes (Soderhall and Cerenius, 1992). It was reported that the immune system of Penaeus chinensis could apparently be activated by oral administration of immunodrugs derived from the land and marine plants (Wang et al., 1995). The immune factors of shrimp haemolymph were successfully stimulated and enhanced resistance was achieved against infectious diseases by the administration of glucans (Song et al., 1993, 1997; Itami et al., 1994; Sung et al., 1994; Chang et al., 2000), peptidoglycans (Takahashi et al., 1995; Itami et al., 1998; Henning et al., 1998) and lipopolysaccharides (Karunasagar et al., 1996).

Agglutination titre was considerably increased in the Ulva treated shrimp. A very high titre of 8192 each was obtained for formalin-killed $V$. fischeri and A. hydrophila antigens (Table 2). In the case of normal shrimp, the titre was 2048 and 4096, respectively. The enhancement was found to be moderate against E. coli (4096), M. luteus (4096) and $P$. aeruginosa (2048) antigens. It was found that the Dendrilla medication did not induce any changes in the titre against E. coli (2048), P. aeruginosa (1024) and A. hydrophila (4096). However, the medication showed moderate enhancement against $V$. fischeri (4096) and $M$. luteus (4096). As the agglutination titre values were the index of level of agglutinin in the 
Table 2

Agglutination titre of normal and treated shrimp

\begin{tabular}{llll}
\hline Bacterial species & \multicolumn{2}{l}{ Experimental groups } & \\
\cline { 2 - 4 } & Control $n=20$ & Ulva-treated $n=20$ & Dendrilla-treated $n=20$ \\
\hline V. fischeri & 2048 & 8192 & 4096 \\
E. coli & 2048 & 4096 & 2048 \\
P. aeruginosa & 1024 & 2048 & 1024 \\
A. hydrophila & 4096 & 8192 & 4096 \\
M. luteus & 2048 & 4096 & 4096 \\
\hline
\end{tabular}

circulation, the enhanced level achieved by the MSMs treatment might elicit a high defense against bacterial pathogens (Selvin, 2002).

The phagocytic rate was significantly increased in the Ulva-treated shrimp (Table 3). The rate of phagocytosis was increased to $5.8 \%, 2.8 \%, 1.56 \%, 1.38 \%$ and $0.66 \%$, respectively, over the normal shrimp against E. coli, $V$. fischeri, P. aeruginosa, A. hydrophila and M. luteus. The Dendrilla-medicated group exhibited enhanced phagocytosis against $E$. coli $(3.8 \%)$ over the control group. However, only a meagre enhancement was observed against $V$. fischeri, $P$. aeruginosa and $A$. hydrophila. The phagocytic cells reported to remove foreign particles in the crustacean haemolymph (Mckay and Jenkin, 1970; Fontine and Lightner 1974; Paterson and Stewart 1974; Paterson et al., 1976; Smith and Ratcliffe 1978, 1980; Goldenberg et al., 1984). The index of phagocytosis indirectly measures the level of pro-phenoloxidase activating system, which initiates haemocyte encapsulation (Hose et al., 1990).

Results of bacterial clearance showed that all the control shrimps cleared $12.0 \%$ of the challenged $V$. fischeri cells within $10 \mathrm{~min}$. During the same interval, the clearance was high, to the extent of $24.0 \%$ and $22.0 \%$ in the Ulva- and Dendrilla-treated groups, respectively (Table 4). The results of viable plate count indicated that $46.0 \%$ was reduced in $30 \mathrm{~min}$, which progressed to $24.46 \%$ in $1 \mathrm{~h}$ in the control group. The clearance was very high to the extent of $64.0 \%$ within $30 \mathrm{~min}$ and $85.0 \%$ in $60 \mathrm{~min}$ in the Ulva-treated group. In the Dendrilla-treated group, a lower clearance of $58.0 \%$ in $30 \mathrm{~min}$ and $82.0 \%$ in 1 $\mathrm{h}$ were recorded. Ulva medication cleared Vibrio cells to the extent of $64 \%$ at $30 \mathrm{~min}$ and $88 \%$ at $60 \mathrm{~min}$, respectively. The plasma bactericidin was reported to effectively combat the bacterial infection in lobsters (Cornick and Stewart, 1968; Mori and Stewart, 1978).

Table 3

Percentage of phagocytosis in the normal and treated shrimp

\begin{tabular}{llll}
\hline Bacterial species & \multicolumn{2}{l}{ Experimental group } & \\
\cline { 2 - 4 } & Control $n=20(\%)$ & Ulva-treated $n=20(\%)$ & Dendrilla-treated $n=20(\%)$ \\
\hline V. fischeri & 49.20 & 52.00 & 49.90 \\
E. coli & 48.80 & 54.60 & 52.60 \\
P. aeruginosa & 42.80 & 44.36 & 42.89 \\
A. hydrophila & 44.90 & 46.28 & 45.56 \\
M. luteus & 45.54 & 46.20 & 45.26 \\
\hline
\end{tabular}


Table 4

Rate of bacterial clearance in the normal and treated shrimp

\begin{tabular}{llll}
\hline Time $(\mathrm{min})$ & \multicolumn{2}{l}{ Experimental group $(n=20)$} & Dendrilla-treated $(\mathrm{cfu} / \mathrm{ml})$ \\
\cline { 2 - 4 } & Control $(\mathrm{cfu} / \mathrm{ml})$ & Ulva-treated $(\mathrm{cfu} / \mathrm{ml})$ & $1.0 \times 10^{6}$ \\
0 & $1.0 \times 10^{6}$ & $1.0 \times 10^{6}$ & $7.8 \times 10^{5}$ \\
10 & $8.8 \times 10^{5}$ & $7.6 \times 10^{5}$ & $4.2 \times 10^{5}$ \\
30 & $4.6 \times 10^{5}$ & $3.6 \times 10^{5}$ & $1.8 \times 10^{5}$ \\
60 & $2.46 \times 10^{5}$ & $1.2 \times 10^{5}$ & \\
\hline
\end{tabular}

According to Sung et al. (1996), about $10 \%$ of the exposed $V$. vulnificus cells were clearedoff within $5 \mathrm{~min}$ and they were completely cleared-off at $24 \mathrm{~h}$. Adams (1991) reported that more than $99 \%$ of heat-killed $V$. alginolyticus were cleared from haemolymph of $P$. monodon within $48 \mathrm{~h}$ after exposure. In the present experiment, $88 \%$ of viable $V$. fischeri cells were cleared-off from the haemolymph within $1 \mathrm{~h}$ in the Ulva-treated group. The rapid bacterial clearance rate of shrimp haemocytes was found to be stimulated by Ulva treatment. Therefore, it was conjectured that bacteridins found in shrimp plasma might be inducibly released from haemocytes by Ulva medication.

The results of in vitro broad-spectrum antibacterial activity of serum are presented in Table 5. The survival index ratio of E. coli, $V$. fischeri, $P$. aeruginosa, A. hydrophila and $M$. luteus were $<1$ following treatment with Ulva. However, the index was $>1$ for $P$. aeruginosa and $A$. hydrophila in the shrimps treated with Dendrilla. In addition, the survival index (SI) of E. coli and M. luteus was greater than 1 in normal and Dendrillatreated shrimp while the same was always less than 1 in the Ulva-treated shrimp. The nature of the bacterial cells also influenced the level of serum bactericidal activity. Among the five bacterial species, the relative rate of clearance in the shrimps treated with Ulva diet were graded as $E$. coli $>M$. luteus $>P$. aeruginosa $>V$. fischeri $>A$. hydrophila in decreasing order. This may be one of the reasons for the consideration of $V$. fischeri and A. hydrophila as shrimp pathogens. The results showed that the normal and Dendrilla shrimp serum did not exhibit antibacterial activity against $P$. aeruginosa and $M$. luteus. These findings suggest the quick production of bactericidins in the haemolymph of Ulva-treated group.

The TVC of gut was drastically reduced following Dendrilla feeding $\left(6.36 \times 10^{3} \mathrm{cfu} /\right.$ $\mathrm{ml})$ and it was almost similar to that of the OTC-treated group $\left(2.84 \times 10^{3} \mathrm{cfu} / \mathrm{ml}\right)$ (Table 6). The TVC of Ulva fed shrimps was $1.06 \times 10^{4} \mathrm{cfu} / \mathrm{ml}$ and it was near to that of the control group $\left(4.08 \times 10^{4} \mathrm{cfu} / \mathrm{ml}\right)$. Findings of the present study indicated that Ulva diet

Table 5

Serum bactericidal activity of normal and treated shrimp

\begin{tabular}{|c|c|c|c|c|c|c|c|c|c|c|}
\hline \multirow[t]{2}{*}{ Group } & \multicolumn{2}{|c|}{ V. fischeri } & \multicolumn{2}{|c|}{ E. coli } & \multicolumn{2}{|c|}{ P. aeruginosa } & \multicolumn{2}{|c|}{ A. hydrophila } & \multicolumn{2}{|c|}{ M. luteus } \\
\hline & $\mathrm{SI}^{\mathrm{a}}$ & $\mathrm{RSI}^{\mathrm{b}}$ & SI & RSI & SI & RSI & SI & RSI & SI & RSI \\
\hline Control & 0.82 & 1.00 & 1.52 & 1.00 & 0.62 & 1.00 & 0.94 & 1.00 & 1.29 & 1.00 \\
\hline Ulva & 0.76 & 0.92 & 0.89 & 0.58 & 0.56 & 0.90 & 0.89 & 0.94 & 0.92 & 0.71 \\
\hline Dendrilla & 0.78 & 0.95 & 1.38 & 0.90 & 0.68 & 1.09 & 0.96 & 1.02 & 1.16 & 0.89 \\
\hline
\end{tabular}

${ }^{\text {a }}$ SI-Survival Index.

${ }^{\mathrm{b}}$ RSI-Ratio of Survival Index. 
Table 6

Total viable count (TVC) of gut content of normal and treated shrimp

\begin{tabular}{lc}
\hline Experimental group & TVC (cfu/ml) \\
\hline Control & $4.08 \times 10^{4}$ \\
OTC fed & $2.84 \times 10^{3}$ \\
Ulva fed & $1.06 \times 10^{4}$ \\
Dendrilla fed & $6.36 \times 10^{3}$ \\
\hline
\end{tabular}

could be used as prophylactic agent while the Dendrilla diet could be used as therapeutic agent.

\section{Acknowledgements}

Authors are thankful to Dr. Mohan Joseph Modayil, Director and Dr. R. Paul Raj, Head, PNP Division, CMFRI, Kochi for the facilities and encouragement. This paper is a part of the $\mathrm{PhD}$ thesis work of JS.

\section{References}

Adams, A., 1991. Response of penaeid shrimp to exposure to Vibrio species. Fish Sellfish Immunol. 1, 59-70. Azad, I.S., Shanker, K.M., Mohan, C.V., 1995. Defense mechanism in shrimps and other crustaceans. Fish. Chimes 160, 17-18.

Bachere, E., Mialhe, E., Noel, D., 1995. Knowledge and research prospects in marine mollusk and crustacean immunology. Aquaculture 132, 17-32.

Braak, C.B.T., Faber, R., Boon, J.H., 1996. Cellular and humoral characteristics of Penaeus monodon (Fabricius, 1798) haemolymph. Comp. Haematol. Int. 6, 194-203.

Chang, C.F., Chen, H.Y., Su, M.S., Liao, I.C., 2000. Immunomodulation by dietary beta-1,3-glucan in the brooders of the black tiger shrimp Penaeus monodon. Fish Shellfish Immunol. 10 (6), 505-514.

Chisholm, J.R.S., Smith, V.J., 1995. Comparison of antibacterial activity in the haemocytes of different crustacean species. Comp. Biochem. Physiol. 110A, 39-45.

Cornick, J.W., Stewart, J.E., 1968. Interaction of the pathogen Gaffkya homari with natural agglutinin. J. Fish. Res. Board Can. 25, 695-709.

Fontaine, C.T., Lightner, D.V., 1974. Observations on the phagocytosis and elimination of carmine particles injected into the abdominal masculature of the white shrimp, Penaeus setiferus. J. Invertebr. Pathol. 24, $141-148$.

Goldenberg, P.Z., Huebner, E., Greenberg, A.H., 1984. Activation of lobster hemocytes for phagocytosis. J. Invertebr. Pathol. 43, 77-88.

Henning, O., Itami, T., Maeda, M., Kondo, M., Natsukari, Y., Takahashi, Y., 1998. Analyses of haemolymph immunoparameters in kuruma shrimp infected with penaeid rod-shaped DNA virus. Fish Pathol. 33, 389-393.

Hose, J.E., Martin, G.G., 1989. Defense function of granulocytes in the Ridgeback prawn Sicyonia igentis. J. Invertebr. Pathol. 53, 335-346.

Hose, J.E., Martin, G.G., Gerard, A.S., 1990. A decapod hemocytes classification scheme integrating morphology, cytochemistry and function. Biol. Bull. 178, 33-45.

Itami, T., Takahashi, Y., Tsuchitra, E., Igusa, H., Kondo, M., 1994. Enhancement of disease resistance of kuruma prawn Penaeus jopnicus and increase in phagocytic activity of prawn haemoacytes after oral administration of ß-1,3 glucan (Schizophyllan). In: Chou, L.M., et al. (Eds.), The Third Asian Fisheries Forum, pp. 375-378. 
Itami, T., Asano, M., Tokushige, K., Kubono, K., Nakagawa, A., Takeno, N., Nishimura, H., Maeda, M., Kondo, M., Takahashi, Y., 1998. Enhancement of disease resistance of kuruma shrimp, Penaeus japonicus, after oral administration of peptidoglycan derived from Bifidobacterium thermophilum. Aquaculture 164, $277-288$.

Johansson, M.W., Keyser, P., Sritunyalucksana, K., Soderhall, K., 2000. Crustacean haemocytes and haematopoiesis. Aquaculture 191, 45-52.

Jones, J.C., 1962. Current concepts concerning insect haemocytes. Am. Zool. 2, 209-246.

Karunasagar, I., Otta, S.K., Karunasagar, I., Joshna, K., 1996. Successful management of white spot disease in shrimp using immunostimulants. Fish. Chimes 161, 49-50.

McKay, D., Jenkin, C.R., 1970. Immunity in the invertebrates. The role of serum factors in phagocytosis of erythrocytes by hemocytes of the freshwater crayfish (Parachaeraps bicarinatus). Aus. J. Exp. Biol. Med. Sci. 48, 139-150.

Mori, K., Stewart, J.E., 1978. Natural and induced bactericidal activity of the hepatopancreas of the American lobster, Homarus americanus. J. Invertebr. Pathol. 32, 171-176.

Paterson, W.D., Stewart, J.E., 1974. In vitro phagocytosis by haemocytes of the American lobster, (Homarus americanus). J. Fish. Res. Board Can. 31, 1051-1056.

Paterson, W.D., Stewart, J.E., Zwicker, B.M., 1976. Phagocytosis as a cellular immune response mechanism in the American lobster Homarus americanus. J. Invertebr. Pathol. 27, 95-104.

Selvin, J., 2002. Shrimp disease management using secondary metabolites isolated from marine organisms. PhD Thesis submitted to MS University. Tirunelveli, India, p. 204.

Selvin, J., Lipton, A.P., 2003a. Shrimp disease management using bioactive marine secondary metabolites: an eco-friendly approach. Naga 26 (1), 11-13.

Selvin, J., Lipton, A.P., 2003b. Proactive management of shrimp bacterial diseases using secondary metabolites isolated from seaweed Ulva fasciata. Aquaculture (submitted for publication).

Smith, V.J., Ratcliffe, N.A., 1978. Host defense reactions of the shore crab, Carcinus maenas (L), in vitro. J. Mar. Biol. Assoc. UK 58, 367-379.

Smith, V.J., Ratcliffe, N.A., 1980. Host defense reactions of the shore crab, Carcinus maenas (L): clearance and distribution of injected test particles. J. Mar. Biol. Assoc. UK 60, 89-102.

Soderhall, K., Cerenius, L., 1992. Crustacean immunity. Annu. Rev. Fish Dis. 2, 3-23.

Song, Y.L., Cheng, W., Wang, C.H., 1993. Isolation and characterization of Vibrio damsela infections for cultured shrimp in Taiwan. J. Invertebr. Pathol. 61, 24-31.

Song, Q., Luo, W., Wang, W., Zhu, J., Xue, Q., Tam, J., Hou, Y., Wang, J., 1997. Scanning electron microscope and pathological studies on the adherent bacteria of surface cuticle of Penaeus chinensis during hatching period. Coast. Eng. 16 (1), 36-40.

Sung, H.H., Kou, G.H., Song, Y.L., 1994. Vibriosis resistance induced by glucan treatment in tiger shrimp (Penaeus monodon). Fish Pathol. 29, 11-17.

Sung, H.H., Yang, Y.L., Song, Y.L., 1996. Enhancement of microbicidal activity in the tiger shrimp Penaeus monodon via immunostimulation. J. Crustac. Biol. 16 (2), 278-284.

Takahashi, Y., Itami, T., Kondo, M., 1995. Immunodefense system of Crustacea. Fish Pathol. 30 (2), $141-150$.

Wang, L., Li, G., Mao, Y., 1995. Measuring methods and variations of some haemolymph factors in Penaeus chinensis after their oral ingestion of immuno drugs. Oceanol. Limnol. Sing. 26 (1), 34-41. 